\title{
Analysis of Articles on Education and Instructional Technologies (Scopus)
}

\author{
https://doi.org/10.3991/ijet.v15i23.18803 \\ Tahir Tavukcu ${ }^{(凶)}$ \\ Ministery of Education and Culture, North Cyprus, Turkey \\ ttavukculgmail.com \\ Aydar M. Kalimullin \\ Kazan Federal University, Kazan, Russia \\ Aleksandr V. Litvinov \\ Moscow State University of Psychology and Education, Moscow, Russia \\ Peoples' Friendship University, Moscow, Russia \\ Natalya N. Shindryaeva \\ I.M. Sechenov First Moscow Medical University, Moscow, Russia \\ Valentina Abraukhova \\ Don State Technical University, Rostov-on-Don, Russia \\ Niyaz M. Abdikeev \\ Financial University under the Government of the Russian Federation, \\ Moscow, Russia
}

\begin{abstract}
It is an indisputable fact that technology is a part of our lives. It is known that research and education technologies are concentrated. By examining the articles and dissertations published in the field, the scope, strengths and weaknesses of the studies were determined. An important gap has been filled in to guide researches what kind of studies may be needed in the future. Many studies for this purpose were found in the literature. However, since similar studies dealing with educational technologies are outdated, this study is considered important in terms of gathering current research trends and results. The aim of this study is to analyse the articles published in the Scopus database on educational technologies and instructional technologies, thematically and methodologically. The study was designed by adopting a case study from qualitative research models. The sample has not been determined for postgraduate dissertations to be included in the study, and it was aimed to reach the whole universe. In this context, all articles have been accessed through the library system of the university in the Scopus database included. The keywords 'educational technologies' and 'instructional technologies' were used in the article search. The document types have been examined by year, by country, by authors, by field research and by place of publication.
\end{abstract}

Keywords-Educational technologies, instructional technologies, research trends, Scopus 


\section{Introduction}

Information has never been static. New information is constantly being added over old information. People learn throughout their lives by nature. The lifelong learning desire raises the question of how to learn. With the start of producing solutions to learning in the concept of educational technology, different dimensions have been discovered by undergoing significant changes with the external factors under its influence. In the literature review, it can be seen that there are many definitions of educational technology [31]. The oldest definition of educational technology is defined as the use of equipment in education. Today, educational technology covers many subjects from technology and human interaction to performance technologies, from computer-aided education to virtual education, from active teacher to passive technique and to teaching with gamification. Educational technology is of great importance in the theories emerging in the field of educational sciences, and in the application of these theories and the development of applications. Educational technologies are generally not only seen as a solution to the real or perceived shortcomings of traditional methods. The purpose of educational technology can also be defined as the tools to reduce inequalities in educational opportunities worldwide $[11,14,16]$. Wired training has been introduced as a technology to improve not only training opportunities but also general access to information.

Rapid developments in technology and science have turned countries into a race course, and this race has become a necessity rather than a privilege to develop new technological opportunities. It is inevitable to keep up with the developing technology and the time. It is necessary to improve by adding technology to education, as our age is developing too. In order to realise the role of education, it is necessary to make efficient use of technology in educational activities. The machines, systems and methods that contribute to the processes of applying science to the problems in production, transportation, service, trade, and that serve as a bridge between science and practice are called technology. Educational technology is called the process required for the design, implementation and development of teaching-learning processes $[1,12,16,18,19,24,25]$. The concept of educational technology has moved away from the initial definition of 'equipment used in education' over time; it has evolved over time and has become a discipline in its own right, covering many areas from technology-human interaction to performance technologies. It plays an important role in understanding its historical development. For this purpose, it is thought that the studies conducted will be a guide in revealing the current trends in the field, in understanding which subjects have reached the saturation and in determining what kind of new researches are needed.

Advances in technology also affect the concept of Science. Developments in science and technology require some changes in educational practices. The use of technology-learning environments is increasing. Educational technology is related to the teaching process and helps to achieve the goals set. However, there is a difference between the concept of educational technology and the concept of instructional technology. 'Instructional technology' is a technology-related term that is regulated depending on the sub-concept of 'teaching' and taking into account the specific 
aspects of certain teaching disciplines, for example, 'science teaching technology'. 'Educational technology', on the other hand, develops, applies and evaluates appropriate designs by employing relevant elements (human power, knowledge, method, technique, equipment, etc.) to systematically analyse the problems involving all aspects of the phenomenon of 'human learning' and to develop solutions for them. It is a complex process. The term 'educational technology' emphasises a discipline related to learning and teaching processes. On the other hand, the term 'instructional technology' expresses the effectiveness of guiding learning in teaching a subject [31].

When the studies conducted were examined, we could see that the studies on educational technology do not have a long history. The joint use of different research approaches in social sciences and behavioural sciences is one of the recurring discussion topics, especially between different positivists or post-positivists and different analyses, namely qualitative or quantitative [29]. Trends in educational technology research attracted the attention of researchers who contributed to their own studies [9,10,15,17,18] Mihalca and [23,32]. Caffarella [4] first evaluated doctoral studies between 1987 and 1988. Again, the same researcher Caffarella [3] evaluated 2,689 dissertations between 1977 and 1998. Caffarella updated the list at different times and between 1977 and 2006 wrote and submitted all doctoral theses to Cortland Services University Library. Goktas et al. [8] study, conducted in the five largest universities in Turkey over the past decade in education technology doctorate, was completed in the field in Anadolu, Ankara, where most of these theses were carried out. In addition to Orta Doğu Teknik, Hacettepe and Marmara universities, a total of 64 thesis examinations were carried out by scanning the library of the Council of Higher Education. The results obtained in this study revealed a variety of subjects related to educational technology in Turkey which have not yet been carried out, and the study concluded that there were serious problems, particularly in terms of internal and external validity in existing studies. Reviews other than the studies by Caffarella and Sachs [4] do not have a quality indexing system. Hranstinski and Keller [10] examined the articles in the Computers and Education, Educational Media International, Journal of Educational Computing Research and Journal of Educational Media; Ross et al. [23], Hew et al. [9] and Masood [19] examined the articles in the Educational Technology Research and Development (ETR \& D); and Latchem [15] examined the articles in the British Journal of Educational Technology.

Every new research that is planned before a research is carried out starts and takes shape with the examination of previous researches. Especially, if we look at the researches in the field of education and training technologies, it is more important to base it on the current literature than on the importance of studies in other fields. The reason for this situation is that technology is a rapidly changing and developing field. Determining research topics is a difficult process for any researcher. The first studies in the field of technology are mostly on the effects of educational software and similar technologies on student achievement and motivation. Due to the convenience and increase in internet environments, researchers have started to examine the role of technology in educational environments in terms of teachers and its effect on the education and training process. In these studies, technology has been considered as an integral part of the education-teaching environment rather than a tool through which 
the teaching content is transferred [7]. In the literature review of instructional technologies, it can be seen that studies are carried out using different research methods, not using the research methods used in different educational settings. There are many meta-analysis studies examining the effects of technology on student achievement [30].

Every new research that is planned before a research is carried out starting with the examination of previous researches and is shaped according to the results. In particular, when researches in the field of education and training technologies are examined, it is more important to be based on an up-to-date literature review compared to the importance of studies in other fields. This research reviews the articles on educational technology and instructional technology published in journals in the Scopus database: Therefore, this research is important in terms of evaluating the results of the studies in the field of educational technologies and teaching technologies regarding the year, the country, the department and their publication type.

\subsection{Purpose and importance of the study}

The purpose of this research is to systematically analyse the articles published in the Scopus database and scan its index by examining it according to the determined themes and discussing them with other related basic concepts. The research will contribute to the studies on future educational technologies and educational technologies.

\section{$2 \quad$ Method}

This study was carried out using qualitative research methodology, content analysis and document analysis. The most important point in content analysis is to interpret similar data within the framework of the determined themes in a way that the reader can understand [26]. Content analysis is a scientific framework that provides systematic analysis of written, oral and other sources. Ozberk and Uzunboylu [22] and Odabasi et al. [21] define content analysis as concise messages in existing documents.

\subsection{Data collection and analysis}

Among those published in the Scopus database, the research was carried out using the keywords 'mobile teaching and the hearing impaired' in the Scopus database, and as a result of this, 232 documents were obtained, as shown in Figure 1. Documents taken from the Scopus database were analysed, linked to each other and integrated, and the data were analysed with content analysis. 


\section{2 document results}

TTTE-ABS-KEY "educational technologies" AND "instructional technologies")

D Edit $\triangle$ Sove $\Delta$ Set alert $₫$ Setfeed

Fig. 1. The documents accessed on Scopus database using the keywords 'educational technologies' and 'instructional technologies'

\section{$3 \quad$ Findings}

\subsection{Distribution of documents by years}

At this stage of the research, the distribution of documents between the years 1978 and 2020 was examined. In this context, 232 studies were accessed through the Scopus database, and their distribution is presented in Table 1.

Table 1. Distribution of documents by years

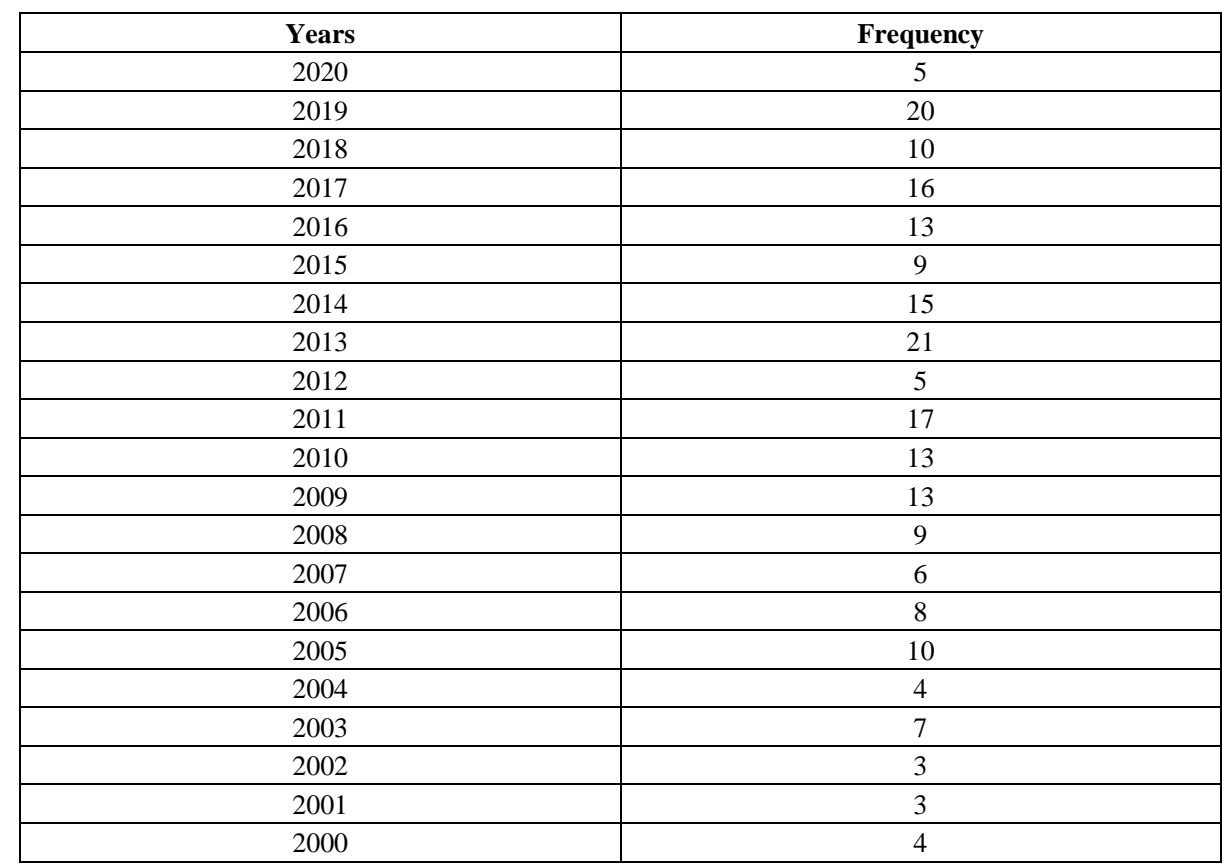

When the studies on educational technology and instructional technologies were examined, it was found that the first study was conducted in 1978. Table 1 includes the studies from 2020 to 2000. There are three studies in 1999, two studies in 1998, four studies in 1996, one study in 1995, one study in 1994, two studies in 1993, one 
study in 1992, one study in 1991, one study in 1989 and two studies in 1986 and 1985. It was found that only one study was conducted in 2003, one study in 1983 and one study in 1978.

\subsection{Distribution of documents by subject areas}

Table 2. Distribution of documents by subject areas

\begin{tabular}{|l|c|}
\hline \multicolumn{1}{|c|}{ Subject area } & f \\
\hline Social Sciences & 184 \\
\hline Computer Science & 64 \\
\hline Psychology & 20 \\
\hline Engineering & 17 \\
\hline Medicine & 17 \\
\hline Nursing & 13 \\
\hline Arts and Humanities & 9 \\
\hline Business, Management and Accounting & 7 \\
\hline Health Professions & 7 \\
\hline Agricultural and Biological Sciences & 6 \\
\hline Mathematics & 6 \\
\hline Biochemistry, Genetics and Molecular Biology & 4 \\
\hline Dentistry & 4 \\
\hline Veterinary & 4 \\
\hline Decision Sciences & 2 \\
\hline Environmental Science & 2 \\
\hline Pharmacology, Toxicology and Pharmaceutics & 2 \\
\hline Chemistry & 1 \\
\hline Economics, Econometrics and Finance & 1 \\
\hline Multidisciplinary & 1 \\
\hline Neuroscience & 1 \\
\hline
\end{tabular}

When the articles in the Scopus database were examined, it was seen that most articles in the field of educational technologies were done in the field of Social Sciences (184). 64 articles were published in the field of Computer Science. One study was conducted in the field of Chemistry (1), Economics (1), Econometrics and Finance Multidisciplinary (1) and Neuroscience (1).

If we look at the findings regarding the types of articles published in the Scopus database, it can be seen that most of the studies were published in the article type; 29 papers were published as conference papers, 21 papers as review, 16 papers as book chapters, 6 papers as book, 2 papers as short survey, 1 paper as conference review and, finally, 1 paper as editorial 


\subsection{Distribution of documents by document types}

Table 3. Distribution of documents by document types

\begin{tabular}{|l|c|}
\hline \multicolumn{1}{|c|}{ Document type } & f \\
\hline Article & 156 \\
\hline Conference paper & 29 \\
\hline Review & 21 \\
\hline Book chapter & 16 \\
\hline Book & 6 \\
\hline Short survey & 2 \\
\hline Conference review & 1 \\
\hline Editorial & 1 \\
\hline
\end{tabular}

\subsection{Source title by Scopus index}

Table 4. Source title by Scopus index

\begin{tabular}{|l|c|}
\hline \multicolumn{1}{|c|}{ Source title } & f \\
\hline Turkish Online Journal of Educational Technology & 26 \\
\hline Educational Technology and Society & 8 \\
\hline ETR \& D & 8 \\
\hline Procedia Social and Behavioural Sciences & 6 \\
\hline Techtrends & 6 \\
\hline Computers in the Schools & 5 \\
\hline American Annals of the Deaf & 4 \\
\hline International Journal of Information and Communication Technology Education & 4 \\
\hline Journal of Computing in Higher Education & 4 \\
\hline Journal of Dental Education & 4 \\
\hline Journal of Veterinary Medical Education & 4 \\
\hline British Journal of Educational Technology & 3 \\
\hline Computers Informatics Nursing & 3 \\
\hline Computers and Education & 3 \\
\hline Education and Information Technologies & 3 \\
\hline Handbook of Research on Educational Communications and Technology Fourth Edition & 3 \\
\hline Journal of Research on Technology in Education & 3 \\
\hline Journal of Science Education and Technology & 3 \\
\hline AI and Society & 2 \\
\hline American Journal of Pharmaceutical Education & 2 \\
\hline
\end{tabular}

When we looked at the analysis of the articles on educational technology and instructional technology published in the Scopus database, it was seen that most of the studies were published in the 'Turkish Online Journal of Educational Technology' (26). There are eight articles published in the Educational Technology and Society and ETR \& D journals, respectively. 


\subsection{Distribution of documents by author's country}

Table 5. Distribution of documents by author's country

\begin{tabular}{|c|c|}
\hline Affiliation & $\mathbf{f}$ \\
\hline United States & 145 \\
\hline \begin{tabular}{|l|} 
Turkey \\
\end{tabular} & 44 \\
\hline Canada & 7 \\
\hline Australia & 3 \\
\hline Cyprus & 3 \\
\hline Singapore & 3 \\
\hline Spain & 3 \\
\hline United Arab Emirates & 3 \\
\hline Brazil & 2 \\
\hline China & 2 \\
\hline Fiji & 2 \\
\hline Germany & 2 \\
\hline Israel & 2 \\
\hline Norway & 2 \\
\hline South Korea & 2 \\
\hline \begin{tabular}{|l|} 
Taiwan \\
\end{tabular} & 2 \\
\hline United Kingdom & 2 \\
\hline Chile & 1 \\
\hline Croatia & 1 \\
\hline France & 1 \\
\hline \begin{tabular}{|l|} 
Ghana \\
\end{tabular} & 1 \\
\hline India & 1 \\
\hline Iran & 1 \\
\hline Italy & 1 \\
\hline Jordan & 1 \\
\hline Macao & 1 \\
\hline Malaysia & 1 \\
\hline Mexico & 1 \\
\hline \begin{tabular}{|l|} 
Philippines \\
\end{tabular} & 1 \\
\hline Slovakia & 1 \\
\hline South Africa & 1 \\
\hline Sweden & 1 \\
\hline Tunisia & 1 \\
\hline Zimbabwe & 1 \\
\hline Undefined & 6 \\
\hline
\end{tabular}

When looking at the countries of the authors of the articles published in the Scopus database, it was found that the most studies were conducted in United States (145), Turkey (44), Canada (7), Australia (3) respectively. When looking at the studies published in Scope, the countries of the authors of six studies were not specified. 


\section{Conclusion and Discussion}

When studies on educational technology and instructional technologies were examined, it was concluded that the first study was conducted in 1978. It was also concluded that most of the studies were done in 2019. Three studies in 1999, two studies in 1998, four studies in 1996, one study in 1995, one study in 1994, two studies in 1993, one study in 1992, one study in 1991 and one study in 1989. The study concluded that two studies were conducted in 1986, one study in 1983 and one study in 1978. When the results of the findings were examined, it can be said that the number of researches is pleasing. The rapid development in technology, in the field of education has increased the studies in this field in recent years.

When the articles on educational technology and instructional technology were examined in the Scopus database, it was seen that most of the articles were in the field of Social Sciences (184). 64 articles were published in the field of Computer Science. It was also concluded that studies were conducted in the fields of Chemistry (1), Economics (1), Econometrics and Finance, Multidisciplinary (1) and Neuroscience (1). This situation can be explained by the fact that the field of social sciences is related to education. In the literature, the issue of using computers in educational technologies and in educational environments is mostly discussed $[5,6,11,9,17,23,27,28]$.

If we look at the analysis of the articles on educational technology and instructional technology published in the Scopus database, it can be seen that most of the studies were published in the 'Turkish Online Journal of Educational Technology' (26). There are 8 articles published in Educational Technology and Society and ETR \& D journals, respectively. This result is consistent with the results in the fields of Social Sciences and Computer Science.

It was observed that studies on educational technologies and instructional technologies were mostly published as articles. 29 papers were conference papers, 21 papers were compilations, 16 were book chapters, 6 were books, 2 papers were short questionnaires, 1 paper was a conference review and, finally, 1 paper was an editorial.

When the countries of the authors of the articles published in the Scopus database were examined, most of them were from the USA (145), followed by Turkey (44), Canada (7) and Australia (3). The countries of the authors of six studies are unclear. They may be from unrecognised countries. It is not surprising that USA, one of the leading developed countries, has the most studies. However, further studies are expected from other countries.

\section{Acknowledgements}

1. The work was performed according to the Russian Government Program of Competitive Growth of Kazan Federal University.

2. The publication has been prepared with the support of the RUDN University Program 5-100. 
3. The work was performed according to the project of improving competitiveness of the leading Russian universities among the leading world scientific education centres "5-100"of First Moscow State Medical University.

4. The work was performed according to the Program of Development of Financial University under the Government of the Russian Federation for 2020.

\section{$6 \quad$ References}

[1] Akoul, M., Lotfi, S., \& Radid, M. (2020). Effects of academic results on the perception of competence and self-esteem in students' training. Global Journal of Guidance and Counseling in Schools: Current Perspectives, 10(1): 12-22. https://doi.org/10.18844/gjgc. v10i1.4874

[2] Amiel, T., \& Reeves, T. C. (2008). Design-based research and educational technology: Rethinking technology and the research agenda. Journal of Educational Technology and Society, 11(4): 29-40.

[3] Caffarella, E. P. (2000). Doctoral dissertation research in educational technology: The themes and trends from 1977 through 1998. In R. M. Branch \& M. A. Fitzgerald (Eds.), Educational media and technology yearbook. Libraries Unlimited.

[4] Caffarella, E. P., \& Sachs, S. G. (1990). Doctoral dissertations in instructional design and technology, 1977 through 1988. Educational Technology Research and Development, 38(3): 39-42. https://doi.org/10.1007/bf02298180

[5] Erdogmus, F. U. (2009). Research trends in CEIT MS and PhD theses in Turkey: A content analysis [Unpublished master's thesis, Middle East Technical University].

[6] Erdogmus, F., \& Cagiltay, K. (2009, Subat). Turkiye'de egitim teknolojileri alanında yapilan master ve doktora tezlerinde genel egilimler. Akademik Bilisim 2009 Konferans1'nda sunulan bildiri. Harran Universitesi.

[7] Dirin, A., Laine, T.., Alamäki, A., (2018). Managing Emotional Requirements in a Context- Aware Mobile Application for Tourists. Int. J. Interact. Mob. Technol. 12, 177. https://doi.org/10.3991/ijim.v12i2.7933

[8] Goktas, Y., Kucuk, S., Aydemir, M., Telli, E., Arpacik, O., Yildirim, G., \& Reisoglu, I. (2012). Educational technology research trends in Turkey: A content analysis of the 20002009 decade. Educational Sciences: Theory and Practice, 12(1): 191-199. https://doi.org/ 10.1016/j.compedu.2013.04.016

[9] Hew, K. F., Kale, U., \& Kim, N. (2007). Past research in instructional technology: Results of a content analysis of empirical studies published in three prominent instructional technology journals from the year 2000 through 2004. Journal of Educational Computing Research, 36(3), 269-300. https://doi.org/10.2190/K3P8-8164-L56J-33W4

[10] Hranstinski, S., \& Keller, C. (2007). An examination of research approaches that underlie research on educational technology: A review from 2000 to 2004. Journal of Educational Computing Research, 36(2): 175-190. https://doi.org/10.2190/H16L-4662-6000-0446

[11] Karademirci, A. H. (2010). Ogretim teknolojileri: Tanimi ve tarihsel gelisimine yeniden bakmak. Akademik Bilisim, 10, 496.

[12] Kay, R. (2020). Analyzing the use of mathematics apps in elementary school classrooms. Contemporary Educational Researches Journal, 10(2): 68-78. https://doi.org/10.18844/c erj.v10i2.4732

[13] Koehler, M. J., \& Mishra, P. (2005). What happens when teachers design educational technology? The development of technological pedagogical content knowledge. Journal of 
Educational Computing Research, 32(2): 131-152. https://doi.org/10.2190/0ew7-01wbbkhl-qdyv

[14] Kurniawan, E., Eva, B., Dafip, M., \& Sriyanto, S. (2020). A teaching-based technology in geography learning. Cypriot Journal of Educational Sciences, 15(4): 766-776. https://doi. org/10.18844/cjes.v15i4.5058

[15] Latchem, C. (2006). A content analysis of the British Journal of Educational Technology. British Journal of Educational Technology, 37(4): 503-511. https://doi.org/10.1111/j.14 67-8535.2006.00635.x

[16] Light, J. S. (2001). Rethinking the digital divide. Harvard Educational Review, 71(4): 709-733. https://doi.org/10.17763/haer.71.4.342x36742j2w4q82

[17] Ma, Y. (2000, February). Research in educational communications and technology at the University of Wisconsin: A study of dissertation completed since the inception of the program. Paper presented at the 22'rd National Convention of the Association for Educational Communications and Technology.

[18] Masood, M. (2004a). A ten-year analysis: Trends in traditional educational technology literature. Malaysian Online Journal of Instructional Technology, 1(2): 73-91.

[19] Masood, M. (2004b). Trends and issues as reflected in traditional educational technology literature: A content analysis. Indiana University.

[20] Mishra, P., Koehler, M. J., \& Kereluik, K. (2009). Looking back to the future of educational technology. TechTrends, 53(5): 49.

[21] Odabasi, M., Uzunboylu, H., Popova, O., Kosarenko, N., \& Ishmuradova, I. (2019). Science education and mobile learning: A content analysis review of the web of science database. International Journal of Emerging Technologies in Learning (iJET), 14(22): 418. https://doi.org/10.3991/IJET.V14I22.11744

[22] Ozberk, K., \& Uzunboylu, H. (2017). A content analysis of the studies on "School Manager and Innovation". Ensayos-Revista De La Facultad De Educacion De Albacete, 32(2): 9-22. https://doi.org/10.18239/ensayos.v32i2.1489 https://doi.org/10.18239/ensa yos.v35

[23] Ross, S. M., Morrison, G. R., \& Lowther, D. L. (2010). Educational technology research past and present: Balancing rigor and relevance to impact school learning. Contemporary Educational Technology, 1(1): 17-35. https://doi.org/10.30935/cedtech/5959

[24] Salama, R., Uzunboylu, H., \& Alkaddah, B. (2020). Distance learning system, learning programming languages by using mobile applications. New Trends and Issues Proceedings on Humanities and Social Sciences, 7(3): 23-47. https://doi.org/10.18844/prosoc.v7i2.50 $\underline{15}$

[25] Seferoglu, S., \& Celen, F. (2020). Improving the use of ICT through online professional development platform based on metacognitive strategies. Global Journal of Information Technology: Emerging Technologies, 10(1): 45-59. https://doi.org/10.18844/gjit.v10i1.47 $\underline{47}$

[26] Simsek, A., Ozdamar, N., Uysal, O., Kobak, K., Berk, C., Kilicer, T., \& Cigdem, H. (2009). Ikibinli yillarda Turkiye'deki egitim teknolojisi arastirmalarında gozlenen egilimler. Kuram ve Uygulamada Egitim Bilimleri Dergisi, 9(2): 115-120. https://doi.org/ 10.1501/egifak_0000000401

[27] Tatar, E., Kagizmanli, T. B., \& Akkaya, A. (2013). Turkiye'deki teknoloji destekli matematik egitimi arastirmalarinin icerik analizi.

[28] Uzunboylu, H., Ozcinar, Z., Kolotushkin, S., Kalugina, O., \& Zulfugarzade, T. (2019). Research and trends in technology and gifted child: Results of a content analysis. International Journal of Emerging Technologies in Learning (iJET), 14(22): 56-69. https:// doi.org/10.3991/IJET.V14I22.11751 
[29] Venkatesh, V., Brown, S., \& Bala, H. (2013). Bridging the qualitative quantitative divide: Guidelines for conducting mixed methods research in information systems. MIS Quart.

[30] Waxman, H. C., Lin, M. F., \& Michko, G. (2003). A meta-analysis of the effectiveness of teaching and learning with technology on student outcomes. Learning Point Associates.

[31] Yildiz, E., Cengel, M., \& Alkan, A. (2020). Current trends in education technologies research worldwide: Meta-analysis of studies between 2015-2020. World Journal on Educational Technology: Current Issues, 12(3): 192-206. https://doi.org/10.18844/wjet. $\mathrm{v} 12 \mathrm{i} 3.5000$

[32] Yusif, Y. (2020). The effectiveness of involving social investments in education. New Trends and Issues Proceedings on Humanities and Social Sciences, 7(3): 71-79. https:// doi.org/10.18844/prosoc.v7i2.5017

\section{Authors}

Tahir Tavukcu completed his Master's and PhD degree in the field of Distance Learning at the same university and department. He received the degree of $\mathrm{PhD}$ in 2015 from Near East Uni veristy and he became an Assistant Professor in 2016. He has been working as an information technology teacher at the Ministry of Education and Culture since 2016. He has been working actively in the field of distance learning at the Ministry of Education and Culture since 2016.

Aydar M. Kalimullin is a Doctor of History, Professor, Head of the Institute of Psychology and Education at Kazan (Volga region) Federal University (18 Kremlyovskaya Street, 420000, Kazan, Russia). He is also the Head of Strategic Academic Unit of Kazan (Volga region) Federal University. His research interests are connected with environmental education, teacher education and training. She has more than 150 published papers in Russian and International journals. E-mail: kalimullin@yandex.ru

Aleksandr V. Litvinov is PhD in Education, 1) Professor of the Chair of Foreign and Russian Philology, Moscow State University of Psychology and Education (MSUPE) (29 Sretenka street, 127051, Moscow, Russia); 2) Associate Professor of the Department Foreign Languages, Faculty of Economics, Peoples' Friendship University of Russia (RUDN University), (6 Miklukho-Maklaya street, 117198, Moscow, Russia). His research interests cover Business English and ESP teaching methodology, discourse analysis, cross-cultural communication, linguistics and psychology. Author and co-author of over 80 publications. E-mail: alisal01@yandex.ru

Natalya N. Shindryaeva is a Doctor of Medicine, Professor of the Department of Nervous Diseases at I.M. Sechenov First Moscow Medical University (Sechenov University) (8 Trubetskaya Street, 119991, Moscow, Russia). She has more than 100 published articles in Russian and International journals. Her research interests are connected with health care education, health care educational technologies. E-mail: mont76@mail.ru

Valentina Abraukhova is a Doctor of Education, Professor at the Department of Theory and Methodology of Vocational Education at Don State Technical University (1, Gagarin square, 344003, Rostov-on-Don, Russia). Her main research interests lie 
in the sphere of non-formal education, lifelong learning and additional education of adults and children. E-mail: childrenpalace@mail.ru

Niyaz M. Abdikeev is a Doctor of Engineering Science, Professor, Director of the Institute of Industrial Policy and Institutional Development at the Financial University under the Government of the Russian Federation (49, Leningradsky Avenue, 125993, Moscow, Russia). His main scientific and professional interest field is connected with neoindustrialization and innovative technologies, innovative economy, and cognitive technologies in economics and management. He is a member of two Dissertation Councils for the defence of doctoral and $\mathrm{PhD}$ theses. He is a member of several scientific, expert and analytical councils, such as the Association of Cognitive Studies, the Russian Association of Artificial Intelligence, etc. He led several research projects on the development and implementation of intelligent control systems, and he has won several national and international scientific grants. Author of more than 230 publications, including 25 monographs and 10 textbooks (including foreign publishers). E-mail: nabdikeev@fa.ru

Article submitted 2020-09-27. Resubmitted 2020-10-23. Final acceptance 2020-10-27. Final version published as submitted by the authors 